\title{
Calibration of an early diagenesis model for high nitrate, low reactive sediments in a temperate latitude estuary (Great Ouse, UK)
}

\author{
B. A. Kelly-Gerreyn ${ }^{1, *}$, D. J. Hydes ${ }^{1}$, M. Trimmer ${ }^{2}$, D. B. Nedwell ${ }^{2}$ \\ ${ }^{1}$ Southampton Oceanography Centre, Empress Dock, Southampton SO14 3ZH, United Kingdom \\ ${ }^{2}$ Department of Biological Sciences, University of Essex, Colchester CO4 3SQ, United Kingdom
}

\begin{abstract}
The description and calibration of a reaction-diffusion model of early diagenesis are presented. Unlike previous models it has been developed for a temperate latitude estuary (Gt Ouse, UK) impacted by high nitrate concentrations (annual mean $700 \mu \mathrm{M}$ ). Five variables, $\mathrm{O}_{2}, \mathrm{NO}_{3}{ }^{-}, \mathrm{NH}_{4}{ }^{+}, \mathrm{SO}_{4}{ }^{2-}$ and $\mathrm{S}^{2-}$, are modelled from the steady state distributions of bulk total organic carbon (TOC) (i.e. a

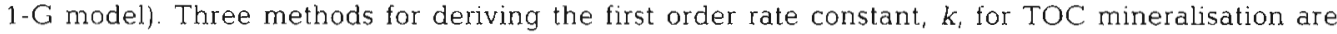
tested: (1) data calculated $k$ values [i.e. (depth integrated total mineralisation rate) $\div$ (depth integrated TOC inventory) ]; (2) an exponential formulation, $k_{z}=k_{0} \mathrm{e}^{-\alpha z}\left(k_{0}=k\right.$ at sediment surface, $\alpha=$ reactivity coefficient of decrease, $z=$ depth); and (3) use of separate $k$ values for individual mineralisation pathways. Method 1 underestimates observed fluxes of solutes across the sediment-water interface (SWI) by up to an order of magnitude. This is due to an inappropriate use of the calculated $k$ in the model. The calculation of $k$ yields an overall net value which implicitly accounts for all factors acting on mineralisation. Such factors (e.g. oxidant limitation of organic decay) are explicitly modelled. Consequently, $k$ is significantly reduced by factors applied to it in the model which have previously been accounted for in the calculation. In Method 2, measured $\mathrm{NO}_{3}{ }^{-}$fluxes are overestimated by up to a factor of 7. To reproduce measured benthic oxygen demands and sulphate reduction rates, $\alpha$ cannot be simultaneously fitted to the $\mathrm{NO}_{3}{ }^{-}$fluxes. The high overlying $\mathrm{NO}_{3}{ }^{-}$concentrations result in model denitrification that cannot reproduce the degree of limitation that actually occurs. Method 3 reproduces the data (i.e. both stoichiometrically derived mineralisation rates and measured solute fluxes at the SWI) to a high degree $(r>0.99, p<0.001)$, but at the expense of increasing the degrees of freedom in the model and conceptual simplicity. These results cast doubt over the universal applicability of diagenetic models for estuarine systems exposed to high $\mathrm{NO}_{3}{ }^{-}$concentrations. It is concluded that the use of commonly calculated first order rate constants (Method 1) and the frequently used exponential function (Method 2) in diagenetic models cannot be relied upon to reproduce observations in high $\mathrm{NO}_{3}{ }^{-}$estuaries. Previous stoichiometric calculations suggested that all of the measured ammonium fluxes across the SWI in the Gt Ouse could be accounted for with oxygen, nitrate and sulphate reduction alone. With these latter processes the model (Method 3) underestimates the observed ammonium fluxes by up to $44 \%$ at 3 out of 4 sites. This suggests that other mineralisation pathways (e.g. nitrate ammonification) are active in the Great Ouse sediments.
\end{abstract}

KEY WORDS: Diagenesis model Rate constant Nutrient fluxes

\section{INTRODUCTION}

The increase in nitrogen loads to coastal environments (Howarth et al. 1996) has led to considerable interest in the role of processes such as denitrification

·E-mail: b.kelly-gerreyn@soc.soton.ac.uk (e.g. Billen 1990) in marine nutrient cycling. Modelling, together with field programmes, helps us to understand the biogeochemical controls of these processes. The Joint Nutrient Study (JoNuS) has investigated the controls on the flux of nutrients from land to the North Sea in 2 major UK estuaries. In this paper we focus on the modelling component of JoNuS with particular emphasis on the Great Ouse estuary (UK). This 
estuary is characterised by exceedingly high concentrations of nitrate (annual mean of $700 \mu \mathrm{M}$, range 250 to $1200 \mu \mathrm{M}$ ) compared to other rivers draining into the North Atlantic (Howarth et al. 1996) and has an annual load of 0.6 to $1 \mathrm{Gmol} \mathrm{NO}_{3}^{-}$(Nedwell \& Trimmer 1996). Nedwell \& Trimmer (1996) calculated that in the fast flowing narrow stretch of the Great Ouse, $\sim 1 \%$ of the nitrogen load was lost by denitrification. This potentially increases to more than $50 \%$ as the sediment surface area to water column ratio increases over the more extensive mudflats of the lower estuary (Trimmer et al. 1998). This model has been developed to investigate the biogeochemical controls on estuarine sedimentary nutrient dynamics.

\section{DIAGENETIC MODELLING}

Dissolved nutrient sediment-water exchanges are driven by the mineralisation of organic matter derived from the water column (via allochthonous and/or autochthonous inputs) or from benthic production. Since the pioneering work of Berner (1980a), many authors (e.g. Rabouille \& Gaillard 1991, Boudreau 1995, Dhakar \& Burdige 1996, Soetaert et al. 1996) have demonstrated that sediment diagenesis can be appropriately described by biogeochemical models which follow a consistent sequence of redox processes. In these models the organic carbon is treated as a substrate which is oxidized by a series of stoichiometric reactions that return part of the nutrients bound in the organic carbon to the water column. Models prior to this work have either been developed for the deep sea (Rabouille \& Gaillard 1991, Dhakar \& Burdige 1996), for global application including shelf sediments (Boudreau 1995, Soetaert et al. 1996) or for coastal and estuarine sediments with low overlying nitrate concentrations (Blackburn \& Blackburn 1993). All these models rely on similar kinetic formulations of organic matter decay. None of them have been applied to coastal systems containing high nutrient concentrations such as those found in the Great Ouse.

In developing this model a 2 stage approach has been adopted. The first stage, presented here, is concerned with a description of the model and its calibration. The intention is to examine a number of different ways to parameterise organic decay with respect to a best-fit to the observed data (Nedwell \& Trimmer 1996). The second stage (Kelly-Gerreyn et al. unpubl.) is the use of the model to examine the temporal (monthly) variability in observed diagenetic processes (Nedwell \& Trimmer 1996). A comparison is made between the stoichiometric models drawn up by Nedwell \& Trimmer (1996) to quantify mineralisation pathways in the Great Ouse sediments and the results from this model which uses kinetic equations.

\section{DESCRIPTION OF THE DATA}

The Great Ouse and Wash is a major river and estuary system on the east coast of England which discharges into the North Sea. Although small on a world scale, the freshwater flow averaged $32 \mathrm{~m}^{3} \mathrm{~s}^{-1}$ and $50 \mathrm{~m}^{3} \mathrm{~s}^{-1}$ in 1992 and 1993, respectively (Nedwell \& Trimmer 1996). The Great Ouse contributed 10\% (1992) and 16\% (1993) of the total UK riverine load of total oxidized nitrogen to the North Sea (Environment Agency unpubl. data). The upper estuary is narrow (<70 $\mathrm{m}$ ), shallow ( 1 to $7 \mathrm{~m}$ at low tide) and predominantly canalized.

Table 1 summarises the sediment characteristics of 4 intertidal sites along the Great Ouse sampled between December 1992 and November 1993 (Nedwell \& Trimmer 1996). The sites, which cover a distance of $25 \mathrm{~km}$ between landward Site 1 and seaward Site 4, are predominantly very fine sandy sediments (63 to $125 \mu \mathrm{m}$ diameter) which have a mean porosity of $0.505 \mathrm{ml} \mathrm{H}_{2} \mathrm{O}$ $\mathrm{ml}^{-1}$ sediment. The molar $\mathrm{C}: \mathrm{N}$ ratios (range, over 4 sites, 26.4 to 55.1 ) and the mean organic carbon content (range 265.87 to $181.27 \mathrm{~mol} \mathrm{C} \mathrm{m}^{-2}$ in top 0 to $15 \mathrm{~cm}$ ) differ between sites. Sites 1 and 2 are essentially freshwater sites (annual high water salinity range of Site $1=$ 0.25 to 0.62 psu) and Sites 3 and 4 are brackish (range 0.51 to 18.86 psu for Site 4). Further information can be found in Nedwell \& Trimmer (1996) and Trimmer et al. (1998).

\section{MODEL ASSUMPTIONS}

Nedwell \& Trimmer (1996) found no change with time or depth in total organic carbon (TOC) profiles. Consequently, this model calculates porewater profiles and concomitant fluxes across the sediment-water interface (SWI) from data-imposed TOC concentrations (Table 1) which are assumed to be at steady state. The model is calibrated using the annually integrated

Table 1 Sediment characteristics for the 4 sites investigated between December 1992 and November 1993. (Adapted from Nedwell \& Trimmer 1996). FS: Fine sand 250 to $125 \mu$ m; VFS: very fine sand 125 to $63 \mu \mathrm{m}$; S: silt/clay $<63 \mu \mathrm{m}$. Porosity: $\mathrm{ml} \mathrm{H}_{2} \mathrm{O} \mathrm{ml} \mathrm{m}^{-1}$ sediment, $\pm \mathrm{SE}, \mathrm{n}=21$. Organic carbon: mean of 4 replicates at 7 depths 1 to $15 \mathrm{~cm}, \pm \mathrm{SE}, \mathrm{n}=21$

\begin{tabular}{|rrrrrrr|}
\hline Site & $\begin{array}{c}\% \text { of top } 5 \mathrm{~cm} \\
\text { of sediment } \\
\end{array}$ & $\begin{array}{c}\text { Mean } \\
\text { FS }\end{array}$ VFS & S & & $\begin{array}{c}\text { Mean organic } \\
\text { carbon } \\
\text { (\% dry wt) }\end{array}$ & $\begin{array}{c}\text { Mean C:N } \\
\text { ratio } \\
\text { (molar) }\end{array}$ \\
\hline 1 & 7 & 76 & 17 & $0.55 \pm 0.02$ & $1.81 \pm 0.12$ & $26.82 \pm 1.1$ \\
2 & 47 & 48 & 5 & $0.46 \pm 0.01$ & $1.42 \pm 0.17$ & $55.50 \pm 3.6$ \\
3 & 26 & 71 & 3 & $0.50 \pm 0.02$ & $1.21 \pm 0.12$ & $36.41 \pm 2.1$ \\
4 & 32 & 58 & 10 & $0.51 \pm 0.01$ & $1.12 \pm 0.12$ & $30.56 \pm 1.1$ \\
\hline
\end{tabular}


data reported in Nedwell \& Trimmer (1996). This removes the observed temporal variability of the solute concentrations, which is examined elsewhere (KellyGerreyn et al. unpubl.). By not modelling TOC, there is no need to account for hydrodynamic or bioturbational solid-phase mixing. However, the lack of depth variations in TOC coupled with active mineralisation (Nedwell \& Trimmer 1996) suggests that either the labile fraction is small compared to the bulk concentration or that the TOC is rapidly mixed in the sediment column. If the latter, the mechanism is likely to be physical rather than bioturbational given the high current shear in the Great Ouse (Gould et al. 1987) and an absence of benthic macro- and meio-fauna on and in the sediments (M. Trimmer pers. comm). Similar annual benthic oxygen demands $\left(23 \mathrm{~mol} \mathrm{O}_{2} \mathrm{~m}^{-2} \mathrm{yr}^{-1}\right.$ and $21 \mathrm{~mol} \mathrm{O}$ $\mathrm{m}^{-2} \mathrm{yr}^{-1}$, Trimmer et al. 1997) for 2 consecutive years (1992-93 and 1993-94, respectively) at seaward Site 4 give additional support for the steady state approach.

The highly refractory sediments (Table 1) coupled with the fact that the Great Ouse is a fast flowing river imply that sediment accumulation (advection) rates are low. We therefore make the simplifying assumption that solute transport is by molecular diffusion and that advection is negligible. However, Nedwell \& Trimmer (1996) reported physically induced subsurface irrigation at one of the sites (2) in the Great Ouse, which may impact on the interpretation of the model results.

Microphytobenthos is not included. Core incubations were kept in the dark (Nedwell \& Trimmer 1996), thereby minimising potential benthic algal activity. Additionally, light-dark incubations of intertidal sediments seawards of Site 4 have revealed no significant differences in nutrient fluxes across the SWI (D. Thornton pers. comm.).

Porosity showed little temporal or spatial variation (Table 1). Consequently, a uniform porosity profile is used in the model, with the assumption that the porosity at the SWI is close to $1(0.99)$.

As the fraction of TOC that is labile is unknown, and since both the molar $\mathrm{C}: \mathrm{N}$ ratio and the TOC concentrations are constant with depth at each site (Table 1), the 1-G model approach has been adopted (Berner 1980a, Tromp et al. 1995, Wang \& Van Cappellen 1996). This assumes a simple first order dependence of organic degradation on the concentration of TOC and has been shown to represent observations well in deep sea sediments (Rabouille \& Gaillard 1991).

Finally, the core incubation experiments used for the Great Ouse sediments (Nedwell \& Trimmer 1996) only account for solute and gas exchange during immersion and ignore deposition-resuspension effects. The model, which is calibrated and validated against this data, is therefore only valid for periods of sediment submergence and ignores processes such as tidal pumping.

\section{MODEL DESCRIPTION}

The model describes the top $15 \mathrm{~cm}$ of sediment with a series of adjoining vertical boxes each of depth $0.1 \mathrm{~cm}$ (Fig, 1). Five variables are modelled: $\mathrm{O}_{2}, \mathrm{NO}_{3}{ }^{-}$, $\mathrm{NH}_{4}{ }^{+}, \mathrm{SO}_{4}{ }^{2-}$ and $\mathrm{S}^{2-}$. The biogeochemical cycling of these solutes occurs in 3 notional zones in the sediment (Fig. 2) in which bacterial degradation of carbon depends upon different oxidising agents. The mineralisation pathways are oxygen, nitrate and sulphate respiration, all of which produce ammonium. Lack of redox processes involving iron, manganese and fermentation is a model limitation caused by the absence of appropriate data for the Great Ouse. This must be considered when assessing the performance of the model.

Sulphide oxidation and nitrification are first order reactions, proportional to the sulphide and ammonium concentrations, respectively, and both processes are limited by the availability of oxygen. Denitrification is limited by nitrate and inhibited by oxygen. This formulation is such that both nitrification and denitrification can occur in the same gridbox. Sulphate reduction is inhibited by both oxygen and nitrate and limited by sulphate availability. The absence of iron and manganese data precludes the modelling of sulphide precipitation/burial processes in these sediments. Any sulphide formed is assumed to be fully available for oxidation. This is reasonable as measurements of total

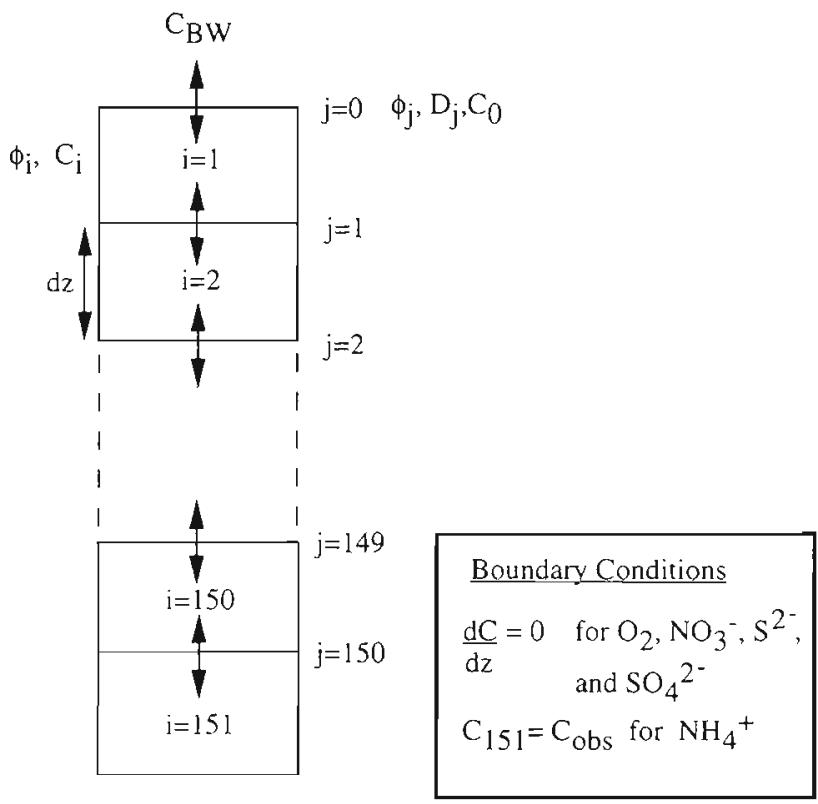

$\mathrm{C}_{\mathrm{BW}}=$ top boundary solute value

$\mathrm{C}_{\text {obs }}=$ bottom boundary solute value

$\mathrm{dz}=$ grid box length $(0.1 \mathrm{~cm})$

Fig. 1. 1-D grid scheme of diagenetic model (see text for details) 


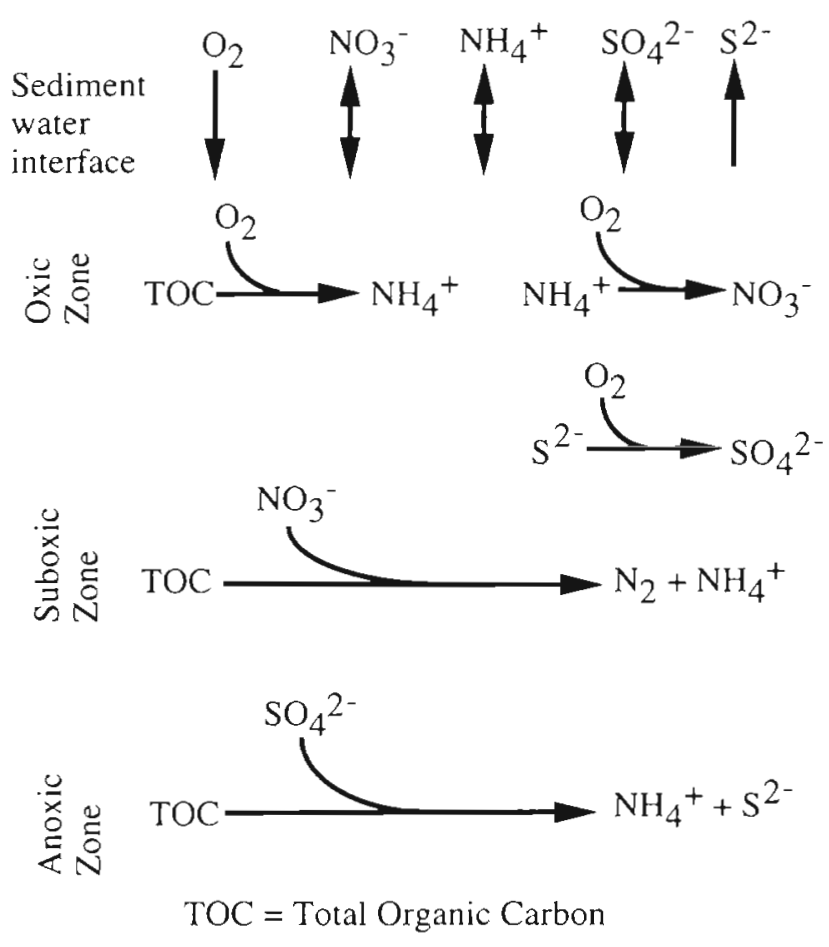

Fig. 2. Biogeochemistry of diagenetic model

sulphide concentrations over the year at the 4 sites suggest that sulphide produced from sulphate reduction did not accumulate (Nedwell \& Trimmer 1996). Finally, since the model is concerned with a steady state description of diagenesis using annually integrated data for calibration, a temperature function is not included in the kinetics of organic decay.

\section{MODEL FORMULATION}

The basic model equation for porewater solutes is derived from the general diagenetic reaction-diffusion equation (Berner 1980a).

$$
\text { Rate of change of } C=-\frac{1}{\phi} \frac{\partial}{\partial z}\left[D_{C} \phi \frac{\partial C}{\partial z}\right]+\sum R
$$

where $C$ is the solute concentration ( $\mathrm{nmol} \mathrm{cm}^{-3}$ of bulk sediment), $\phi$ is the porosity (dimensionless), $D_{C}$ is the sediment diffusion coefficient for $C\left(\mathrm{~cm}^{2} \mathrm{~d}^{-1}\right)$ adjusted for tortuosity and temperature, $z$ is the depth $(\mathrm{cm})$ and $R$ is the set of reaction terms that includes organic decay (Eq. 2 and Table 2). There is no time dependency (i.e. steady state is assumed) and so the lefthand side of Eq. (1) is set to zero.

The kinetics of organic matter degradation are based on a modification of the Monod Law in which the rate is first order with respect to the organic carbon content
$(G)$ and limited by the concentration of the electron acceptor $\left(O x_{1}\right)$. Except in oxygen respiration, inhibition of organic decay by other oxidants, $\mathrm{Ox}_{2}$ (e.g. $\mathrm{O}_{2}$ in denitrification), is included, i.e.

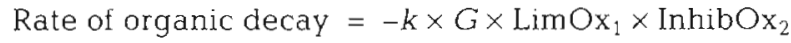
where

$$
\operatorname{LimOx_{1}}=\frac{\mathrm{Ox}_{1}}{O \mathrm{x}_{1}+K_{\mathrm{s}}} \text { and InhibOx } 2=1-\frac{\mathrm{Ox}_{2}}{O \mathrm{x}_{2}+K_{\mathrm{nhh}}}
$$

$k$ is the first order rate constant for organic decay, $K_{\mathrm{s}}$ is the Monod constant, LimOx ${ }_{1}$ is the limitation function due to oxidant concentration $\mathrm{Ox}_{1}$, InhibOx $\mathrm{x}_{2}$ is the inhibition function due to oxidant concentration $\mathrm{Ox}_{2}$ and $K_{1 n h}$ is the inhibition constant. The use of InhibOx 2 and LimOx $x_{1}$ allows a single equation for each variable to be applied continuously over the entire model depth range and provides direct coupling between the various constituents (Rabouille \& Gaillard 1991, Soetaert et al. 1996). Both inhibition and limitation functions are used to model the sequence of organic matter degradation correctly (Soetaert et al. 1996).

The sediment diffusion coefficient $\left(D_{C}\right)$ in Eq. (1) is calculated from tortuosity and temperature following Ullman and Aller (1982) and Soetaert et al. (1996). Thus,

$$
D_{C}=\phi^{m}\left(D_{C}^{0}+D_{C}^{\text {const }} T\right)
$$

where $D_{C}^{0}$ is the $0^{\circ} \mathrm{C}$ free solution diffusion coefficient, $D_{C}^{\text {const }}$ is an ion specific constant (Li \& Gregory 1974), $T$ is the mean temperature and $m$ is an exponent. Here, $m=1.3$, the lower range value reported for sandy sediments (Iverson \& Jørgensen 1993).

The loss of oxidants through organic matter degradation is modelled using stoichiometric ratios determined from Eqs. (4), (5) \& (6).

$\left(\mathrm{CH}_{2} \mathrm{O}\right)_{106}\left(\mathrm{NH}_{3}\right)_{16}+106 \mathrm{O}_{2}=106 \mathrm{CO}_{2}+16 \mathrm{NH}_{3}+106 \mathrm{H}_{2} \mathrm{O}$

$\left(\mathrm{CH}_{2} \mathrm{O}\right)_{106}\left(\mathrm{NH}_{3}\right)_{16}+84.8 \mathrm{HNO}_{3}=106 \mathrm{CO}_{2}+16 \mathrm{NH}_{3}+$ $42.4 \mathrm{~N}_{2}+148.4 \mathrm{H}_{2} \mathrm{O}$

$\left(\mathrm{CH}_{2} \mathrm{O}\right)_{106}\left(\mathrm{NH}_{3}\right)_{16}+53 \mathrm{SO}_{4}{ }^{2-}=106 \mathrm{CO}_{2}+53 \mathrm{~S}^{2-}+16 \mathrm{NH}_{3}+$ $106 \mathrm{H}_{2} \mathrm{O}$

The full set of model equations is shown in Table 2 and associated parameters are defined in Table 3.

\section{INITIALISATION AND BOUNDARY CONDITIONS}

The observed invariant distribution of organic carbon (Table 1) is imposed at all sites in the model. Initial conditions at each site are derived from the 7 mo mean of measurements of porewater profiles for oxygen, nitrate, ammonium and sulphate. The free porewater sulphide is arbitrarily set to $10 \mu \mathrm{M}$ in each model box. Boundary conditions are shown in Table 4. Note that the ammonium concentration is fixed at the bottom 
Table 2. Model equations for each variable. $D$ is the diffusion term in Eq. (1). The remaining terms represent the sum of $R$ reactions in Eq. (1). Parameter definitions and values are in Table 3

\begin{tabular}{|c|c|c|}
\hline Variable & Equation & No. \\
\hline $\mathrm{O}_{2}$ & 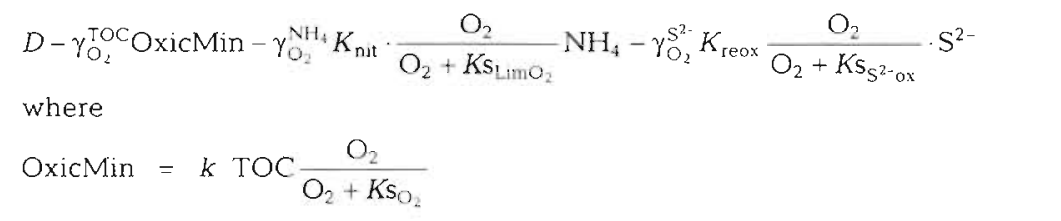 & (7) \\
\hline $\mathrm{NO}_{3}^{-}$ & $\begin{array}{l}D-\gamma_{\mathrm{NO}_{3}}^{\mathrm{TOC}} \text { SuboxMin }+K_{\mathrm{nut}} \cdot \frac{\mathrm{O}_{2}}{\mathrm{O}_{2}+K \mathrm{~K}_{\mathrm{LimO}_{2}}}-\mathrm{NH}_{4} \\
\text { where } \\
\text { SuboxMin }=k \cdot \mathrm{TOC} \frac{\mathrm{NO}_{3}}{\mathrm{NO}_{3}+K_{\mathrm{NO}_{3}}}\left[1-\frac{\mathrm{O}_{2}}{\mathrm{O}_{2}+\mathrm{Ks}_{\mathrm{inhO}_{2}}}\right]\end{array}$ & (8) \\
\hline $\mathrm{SO}_{4}{ }^{2-}$ & $\begin{array}{l}D-\gamma_{\mathrm{SO}_{4}}^{\mathrm{TOC}} \mathrm{AnoxMin}+K_{\text {reox }} \cdot \frac{\mathrm{O}_{2}}{\mathrm{O}_{2}+K \mathrm{SS}_{\mathrm{S}^{2-o x}}} \mathrm{~S}^{2-} \\
\text { where } \\
\left.\text { AnoxMin }=k \cdot \operatorname{TOC} \frac{\mathrm{SO}_{4}}{\mathrm{SO}_{4}+K \mathrm{SSO}_{4}}\left[1-\frac{\mathrm{O}_{2}}{\mathrm{O}_{2}+K \mathrm{~S}_{\mathrm{Anox}_{\mathrm{nnhO}}}}\right] 1-\frac{\mathrm{NO}_{3}}{\mathrm{NO}_{3}+K \mathrm{~S}_{\mathrm{AnoxinhNO}_{3}}}\right]\end{array}$ & (9) \\
\hline $\mathrm{NH}_{4}{ }^{+}$ & 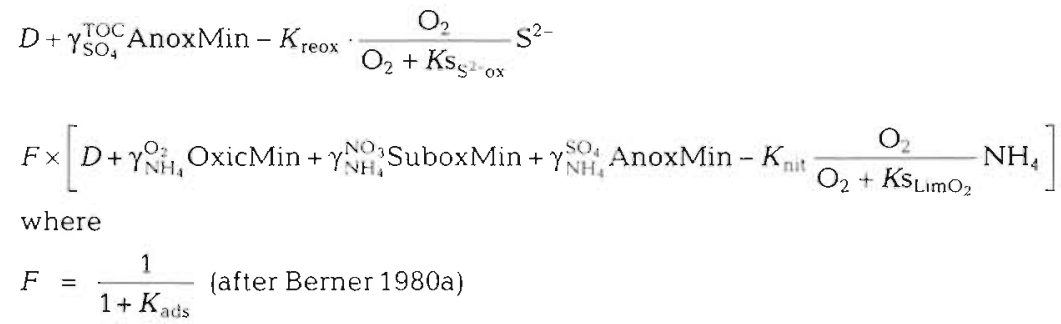 & (11) \\
\hline
\end{tabular}

boundary to provide a continuous flux across this boundary. This is because porewater profiles for ammonium were linear with depth, indicating continued ammonification beyond $15 \mathrm{~cm}$ into the sediment.

\section{THE NUMERICAL SCHEME AND ITS SOLUTION}

The numerical scheme is similar to that of Soetaert et al. (1996). All grid cells, each of equal length $\mathrm{d} z$ (Soetaert et al. 1996 use unequal length grid boxes), are indexed by a number $i$ which is defined in the middle of a box (Fig. 1). Thus, solute concentrations are modelled at the centre of each grid cell. The $i$ indices run from 1 at the top of the sediment to 150 at the bottom. The interfaces between boxes, including the SWI, are defined by a $j$-index which runs from 0 (the SWI) to 150 (the lower boundary of box $i=150$ ). Porosities are defined both at $j$ and $i$ indices while sediment diffusion coefficients are defined only at $j$ positions. The porosity at $i=$ 1 is derived by linearly interpolating the values of $\phi$ between the SWI $(j=0)$ and $j=1$ at each site. For $j \geq 1$ and $i>1$, the porosity-depth gradient is zero and the porosity values are set to those shown in Table 1 . This yields a sharp porosity gradient which is confined to the first model layer. The authors are aware that porosity gradients have a strong influence on diagenetic processes (Rabouille \& Gaillard 1991, Soetaert et al. 1996). However, given the resolution of the sampling method $(1 \mathrm{~cm}$ slices of sediment), the sharp porosity gradient must be implemented in the model. That is, the porosity measured represents the average porosity for the sediment depth interval $(1 \mathrm{~cm})$. Thus, the model porosity profile, when integrated over a $1 \mathrm{~cm}$ sediment slice, must yield the observed porosity in that slice. As the porosity at the SWI must be close to 1 , the model porosity profile must decline sharply to represent the observed porosity.

The diffusion term in Eq. (1) is approximated by direct differencing (see Appendix 1). This ensures mass conservation, even in the presence of sharp porosity gradients (Van Cappellen et al. 1993). The equations ( 7 to 11 ) are solved with an iterative Newton-Raphson type procedure obtained from the LINPACK FORTRAN library at the ftp site netlib.att.com. 
Table 3. Parameter values and their origins

\begin{tabular}{|c|c|c|c|}
\hline Parameter & Description & Value & Source \\
\hline$D_{0}^{0}$ & $\mathrm{O}_{2}$ molecular diffusion coefficient at $0^{\circ} \mathrm{C}$ & $182.59 \mathrm{~cm}^{2} \mathrm{yr}^{-1}$ & Soetaert et al. (1996) \\
\hline$D_{\mathrm{NO}}^{0}$ & $\mathrm{NO}_{3}{ }^{-}$molecular diffusion coefficient at $0^{\circ} \mathrm{C}$ & $308.42 \mathrm{~cm}^{2} \mathrm{yr}^{-1}$ & Soetaert et al. (1996) \\
\hline$D_{\mathrm{NH}_{4}}^{Q}$ & $\mathrm{NH}_{4}{ }^{+}$molecular diffusion coefficient at $0^{\circ} \mathrm{C}$ & $309.05 \mathrm{~cm}^{2} \mathrm{yr}^{-1}$ & Soetaert et al. (1996) \\
\hline$D_{\mathrm{SO}_{4}}^{\mathrm{U}}$ & $\mathrm{SO}_{4}{ }^{2-}$ molecular diffusion coefficient at $0^{\circ} \mathrm{C}$ & $157.68 \mathrm{~cm}^{2} \mathrm{yr}^{-1}$ & Li \& Gregory (1974) \\
\hline$D_{S^{2}}^{0}$ & $\mathrm{~S}^{2-}$ molecular diffusion coefficient at $0^{\circ} \mathrm{C}$ & $307.32 \mathrm{~cm}^{2} \mathrm{yr}^{-1}$ & Soetaert et al. (1996) \\
\hline$D_{O_{2}}^{\text {canst }}$ & Temperature coeff for $\mathrm{O}_{2}$ diffusion coefficient & $14.09 \mathrm{~cm}^{2} \mathrm{yr}^{-1}\left({ }^{\circ} \mathrm{C}\right)^{-1}$ & Soetaert et al. (1996) \\
\hline$D_{\mathrm{NO}:}^{\mathrm{consi}}$ & Temperature coeff. for $\mathrm{NO}_{3}{ }^{-}$diffusion coefficient & $12.26 \mathrm{~cm}^{2} \mathrm{yr}^{-1}\left({ }^{\circ} \mathrm{C}\right)^{-1}$ & Soetaert et al. (1996) \\
\hline$D_{\mathrm{NH}}^{\text {const }}$ & Temperature coeff. for $\mathrm{NH}_{4}{ }^{*}$ diffusion coefficient & $12.16 \mathrm{~cm}^{2} \mathrm{yr}^{-1}\left({ }^{\circ} \mathrm{C}\right)^{-1}$ & Soetaert et al. (1996) \\
\hline$D_{S O_{a}}^{\text {const }}$ & Temperature coeff. for $\mathrm{SO}_{4}{ }^{2-}$ diffusion coefficient & $6.83 \mathrm{~cm}^{2} \mathrm{yr}^{-1}\left({ }^{\circ} \mathrm{C}\right)^{-1}$ & Calculated from data ${ }^{a}$ \\
\hline$D_{S}^{\text {ganst }}$ & Temperature coeff. for $\mathrm{S}^{2-}$ diffusion coefficient & $8.83 \mathrm{~cm}^{2} \mathrm{yr}^{-1}\left({ }^{\circ} \mathrm{C}\right)^{-1}$ & Soetaert et al. (1996) \\
\hline$K_{\text {åds }}$ & $\mathrm{NH}_{4}{ }^{+}$adsorption coefficient & 1.18 & Calculated from data ${ }^{b}$ \\
\hline$K_{\text {nIt }}$ & Rate constant for nitrification & $12520 \mathrm{yr}^{-1}$ & Soetaert et al. (1996) \\
\hline$K_{\text {reax }}$ & Rate constant for sulphide reoxidation & $3.15 \times 10^{6} \mathrm{yr}^{-1}$ & Calculated $^{c}$ \\
\hline$K_{\mathrm{SNO}_{3}}$ & $\begin{array}{l}\text { Half saturation constant for } \mathrm{NO}_{3}^{-} \text {limitation in } \\
\text { denitrification }\end{array}$ & $30 \mu \mathrm{M}$ & Soetaert et al. (1996) \\
\hline$K_{\mathrm{S}_{2}}$ & $\begin{array}{l}\text { Half saturation constant for } \mathrm{O}_{2} \text { limitation in } \\
\text { oxic mineralisation }\end{array}$ & $3 \mu \mathrm{M}$ & Soetaert et al. (1996) \\
\hline$K_{\mathrm{SO}_{4}}$ & $\begin{array}{l}\text { Half saturation constant for } \mathrm{SO}_{4}^{2-} \text { limitation } \\
\text { in sulphate reduction }\end{array}$ & $1600 \mu \mathrm{M}$ & Van Cappellen et al. (1993) \\
\hline$K_{\mathrm{S}_{\mathrm{AnoxInhO}}}$ & $\begin{array}{l}\text { Half saturation constant for } \mathrm{O}_{2} \text { inhibition in } \\
\text { anoxic mineralisation }\end{array}$ & $8 \mu \mathrm{M}$ & Soetaert et al. $(1996)$ \\
\hline$K_{\mathrm{SAnox}_{\mathrm{InhNO}}}$ & $\begin{array}{l}\text { Half saturation constant for } \mathrm{NO}_{3}{ }^{-} \text {inhibition in } \\
\text { anoxic mineralisation }\end{array}$ & $30 \mu \mathrm{M}$ & Soetaert et al. (1996) \\
\hline$K_{\mathrm{SLImO}_{2}}$ & $\begin{array}{l}\text { Half saturation constant for } \mathrm{O}_{2} \text { limitation in } \\
\text { nitrification }\end{array}$ & $1 \mu \mathrm{M}$ & Soetaert et al. (1996) \\
\hline$K_{\mathrm{S}_{\text {InhO}}}$ & $\begin{array}{l}\text { Half saturation constant for } \mathrm{O}_{2} \text { inhibition in } \\
\text { denitrification }\end{array}$ & $6.25 \mu \mathrm{M}$ & Soetaert et al. (1996) \\
\hline$K_{S_{S}{ }^{2} \alpha x}$ & $\begin{array}{l}\text { Half saturation constant for } \mathrm{O}_{2} \text { limitation in } \\
\text { sulphide reoxidation }\end{array}$ & $1 \mu \mathrm{M}$ & Soetaert et al. (1996) \\
\hline $\mathrm{\gamma O}_{2}^{\mathrm{TOC}}$ & $\mathrm{Mol} \mathrm{O}_{2}$ used per mol C used in oxic mineralisation & 1 & Nedwell \& Trimmer (1996) \\
\hline $\mathrm{Y}_{\mathrm{NO}_{3}}^{\mathrm{TOC}}$ & $\mathrm{Mol} \mathrm{NO}_{3}{ }^{-}$used per mol C used in suboxic mineralisation & $4 / 5$ & Nedwell \& Trimmer (1996) \\
\hline$\gamma_{\mathrm{SO}_{3}}^{\mathrm{TOC}}$ & $\mathrm{Mol} \mathrm{SO}{ }_{4}{ }^{2-}$ used per mol $\mathrm{C}$ used in anoxic mineralisation & $1 / 2$ & Nedwell \& Trimmer (1996) \\
\hline$\gamma_{N H}^{x}$ & $\begin{array}{l}\text { Mol } \mathrm{NH}_{4}{ }^{+} \text {produced per mol } \mathrm{C} \text { used in mineralisation } \\
\text { via } \mathrm{X}, \mathrm{X}=\mathrm{O}_{2}, \mathrm{NO}_{3}{ }^{-}, \mathrm{SO}_{4}{ }^{2-}\end{array}$ & $1 /(\mathrm{C}: \mathrm{N})$ & Nedwell \& Trimmer (1996) \\
\hline$\gamma_{\mathrm{O}_{2}}^{\times}$ & $\mathrm{Mol} \mathrm{O} \mathrm{O}_{2}$ used per mol $\mathrm{X}$ used in reoxidation; $\mathrm{X}=\mathrm{NH}_{4}{ }^{+}, \mathrm{S}^{2-}$ & 2 & Soetaert et al. (1996) \\
\hline \multicolumn{4}{|c|}{ 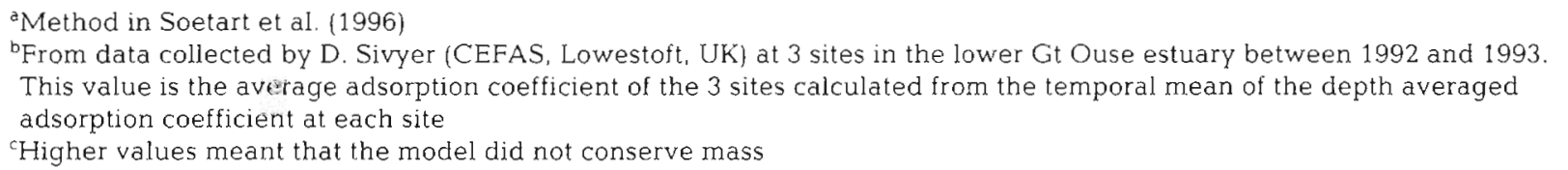 } \\
\hline
\end{tabular}

Table 4 . Boundary conditions and values ( 7 mo mean, units: $\mu M$ ) at the 4 sites. $Z_{f}$ : zero flux condition

\begin{tabular}{|c|c|c|c|c|c|c|c|c|c|c|}
\hline \multirow[t]{2}{*}{ Site } & \multicolumn{5}{|c|}{ Top boundary } & \multicolumn{5}{|c|}{ Bottom boundary (at $15 \mathrm{~cm}$ ) } \\
\hline & $\mathrm{O}_{2}$ & $\mathrm{NO}_{3}^{-}$ & $\mathrm{NH}_{4}^{+}$ & $\mathrm{SO}_{4}{ }^{2-}$ & $S^{2-}$ & $\mathrm{O}_{2}$ & $\mathrm{NO}_{3}^{-}$ & $\mathrm{NH}_{4}{ }^{+}$ & $\mathrm{SO}_{4}{ }^{2-}$ & $\mathrm{S}^{2-}$ \\
\hline 1 & 350 & 654 & 8.2 & 1692 & 0 & $Z_{1}$ & $Z_{1}$ & 1052 & $Z_{i}$ & $\mathrm{Z}_{\mathrm{f}}$ \\
\hline 2 & 350 & 635 & 6.4 & 1630 & 0 & $z_{f}$ & $Z_{f}$ & 176 & $z_{4}$ & $Z_{f}$ \\
\hline 3 & 350 & 724 & 3.8 & 1739 & 0 & $Z_{1}$ & $z_{1}$ & 1164 & $Z_{1}$ & $\mathrm{Z}_{\mathrm{i}}$ \\
\hline 4 & 350 & 694 & 17.3 & 2794 & 0 & $Z_{1}$ & $Z_{i}$ & 1858 & $Z_{f}$ & $Z_{i}$ \\
\hline
\end{tabular}


Table 5. Calculation of $k_{\text {calc }}$ for each site in the Gt Ouse estuary (see text for further details). TOC and $\mathrm{C}_{\text {Ox-rate }}$ data from Nedwell \& Trimmer (1996) integrated over 0 to $15 \mathrm{~cm}$

\begin{tabular}{|lccc|}
\hline Site & $\begin{array}{c}\text { TOC } \\
\left(\mathrm{mol} \mathrm{m}^{-2}\right)\end{array}$ & $\begin{array}{c}\mathrm{C}_{\text {Ox-rate }}{ }^{\mathrm{a}} \\
\left(\mathrm{mol} \mathrm{m}^{-2} \mathrm{yr}^{-1}\right)\end{array}$ & $\begin{array}{c}k_{\text {calc }} \\
\left(\mathrm{yr}^{-1}\right)\end{array}$ \\
\hline 1 & 265.87 & 15.87 & 0.0597 \\
2 & 243.63 & 15.60 & 0.0640 \\
3 & 199.13 & 30.09 & 0.1510 \\
4 & 181.27 & 31.67 & 0.1750 \\
& & & \\
& & & \\
& & &
\end{tabular}

\section{Parameterising the first order rate constant for organic decay $k$}

$k$ (see Eq. 2 and Table 2) represents the reactivity of organic material and, to a lesser extent, the efficiency of bacterial degradation (Van Cappellen et al. 1993). Four methods could be used to derive $k$ : (1) by direct calculation from data yielding $k_{\text {caic }}$ (2) by defining $k$ at any depth, $z$, with an exponential function of the form

$$
k_{z}=k_{0} \mathrm{e}^{-\alpha z}
$$

in which the parameters $k_{0}$ ( $k$ in box $i=1$, Fig. 1$)$ and $\alpha$ (the coefficient of decrease) are fitted to measured solute fluxes across the SWI; (3) by fitting a separate $k$ to a combination of stoichiometrically determined mineralisation rates and observed solute fluxes across the SWI (thereby deriving $k_{02}, k_{\text {no3 }}$ and $k_{\text {so } 4}$ for oxic, suboxic and anoxic mineralisation, respectively); and (4) by fitting equations similar to Eq. (2) (without $\mathrm{LimOx}_{1}$ and InhibOx $x_{2}$ ) to organic carbon profiles. Only Methods 1, 2 and 3 are investigated since Method 4 requires a non-zero depth gradient for TOC. All methods are subjected to inhibition and limitation functions (see Eq. 2). In Method 1, $k$ was calculated from the annually integrated data of Nedwell \& Trimmer (1996). As an example, division of the total mineralisation rate derived stoichiometrically at Site $4\left(31.67 \mathrm{~mol} \mathrm{C} \mathrm{m} \mathrm{m}^{-2}\right.$ $\mathrm{yr}^{-1}$, Table 5) by the depth integrated TOC concentration in the top $15 \mathrm{~cm}$ of sediment $\left(181.27 \mathrm{~mol} \mathrm{C} \mathrm{m}^{-2}\right.$, Table 5) yields $k_{\text {calc }}$ for total mineralisation of $0.175 \mathrm{yr}^{-1}$. Similar calculations give $k$ at each site (Table 5). The derivation of $k$ in this way takes no account of the actual depth over which mineralisation was taking place. A constant $k$ throughout the sediment column (Method 1) assumes equal maximum degradation rates for the different mineralisation pathways and is the approach adopted by most diagenetic models (e.g. Soetaert et al. 1996).

From hereon, model runs are termed according to the kinetic method used. Thus, $M_{\text {calc }}$ is the run using Method 1, $M_{\text {exp }}$ uses Method 2 and model run $M_{1, t}$ uses
Method 3. It is important to note that $M_{\text {calc }}$ does not involve a fitting process. In contrast, both $M_{\mathrm{it}}$ and $\mathrm{M}_{\mathrm{exp}}$ results are derived by a calibration and fitting process. The output from the application of Methods 2 and 3 is that achieved with best fit parameter values.

\section{RESULTS}

\section{Values of $k$}

Table 5 shows the calculated $k_{\text {calc }}$ values for the $M_{\text {caic }}$ runs at the 4 sites in the Great Ouse. The values increase by a factor of $\sim 3$ between Sites $1\left(0.0597 \mathrm{yr}^{-1}\right)$ and 4 $\left(0.175 \mathrm{yr}^{-1}\right)$. In Table 6 , the values of $k$ for model runs $M_{\text {exp }}$ and $M_{t i t}$ are shown for all sites. The fitted values of $k_{0}$ (Table 6 ) for the $M_{\exp }$ runs increase by a factor of 3.8 between sites 1 and 4 . The coefficient of decrease, $\alpha$, is least $\left(0 \mathrm{~cm}^{-1}\right)$ at Site 1 and greatest $\left(9 \mathrm{~cm}^{-1}\right)$ at Site 2 .

$M_{\mathrm{fit}}$ values at Sites 2 and 3 yield similar patterns i.e. $k_{\mathrm{o} 2}>k_{\mathrm{so} 4}>k_{\mathrm{no} 3}$. In contrast, at site $4 k_{\mathrm{o} 2}>k_{\mathrm{no} .3}>k_{\mathrm{s} 04}$. At Site $1, k_{\mathrm{s} 04}$ is approximately 1 and 2 orders of magnitude greater than $k_{02}$ and $k_{\text {no3 }}$ respectively. Intersite differences show that $k_{02}$ increases by a factor of $\sim 11$ between Sites 1 and 4 while no such pattern is seen for $k_{\text {no3 }}$ and $k_{\text {so } 4}$

\section{SWI fluxes}

Fig. 3a-c shows the site by site comparison of modelled $\left(M_{\text {calc }}, M_{\text {exp }}, M_{f i t}\right)$ and observed SWI fluxes for oxygen, nitrate and ammonium. $M_{\text {calc }}$ underestimates all measured fluxes by an average of $66 \%$ (Fig. $3 \mathrm{a}-\mathrm{C}$ ). The only exceptions are for nitrate (Fig. 3b) and ammonium (Fig. 3c) at Site 3, where model fluxes are similar to measurements.

$M_{\text {exp }}$ fluxes of oxygen (Fig. 3a) are well correlated $(r=0.96, n=4, p=0.02)$ to the data. In contrast, $M_{\text {exp }}$

Table 6 . Values of $k$ for model runs $M_{f i l}$ and $M_{\exp }$ derived by fitting the model to stoichiometrically determined mineralisation rates (Nedwell \& Trimmer 1996). Units: $\mathrm{yr}^{-1}\left(k_{\mathrm{o} 2}=k\right.$ for oxic mineralisation; $k_{\text {no3 }}=k$ for suboxic mineralisation; $k_{504}=$ $k$ for anoxic mineralisation; $k_{0}=k$ in top sediment model box [box $i=1$, Fig. 1]); $\alpha$ : coefficient of decrease; $z$ : depth. (See text for further details)

\begin{tabular}{|c|c|c|c|c|c|}
\hline \multirow[t]{2}{*}{ Site } & \multicolumn{3}{|c|}{ Fitted $\left(\mathrm{M}_{\mathrm{tit}}\right)$} & \multicolumn{2}{|c|}{$\begin{array}{l}\text { Exponential (M }\left(\mathrm{M}_{\mathrm{exp}}\right) \\
\qquad k_{z}=k_{0} \mathrm{e}^{-u z}\end{array}$} \\
\hline & $k_{\circ 2}$ & $k_{\text {no3 }}$ & $k_{\text {s04 }}$ & $k_{0}$ & $\alpha\left(\mathrm{cm}^{-1}\right)$ \\
\hline 1 & 1.23 & 0.24 & 34.7 & 5.68 & 0.0 \\
\hline 2 & 7.85 & 0.0004 & 0.06 & 17.34 & 9.0 \\
\hline 3 & 12.39 & 0.19 & 5.23 & 19.55 & 1.5 \\
\hline 4 & 13.40 & 3.63 & 0.25 & 22.08 & 5.2 \\
\hline
\end{tabular}



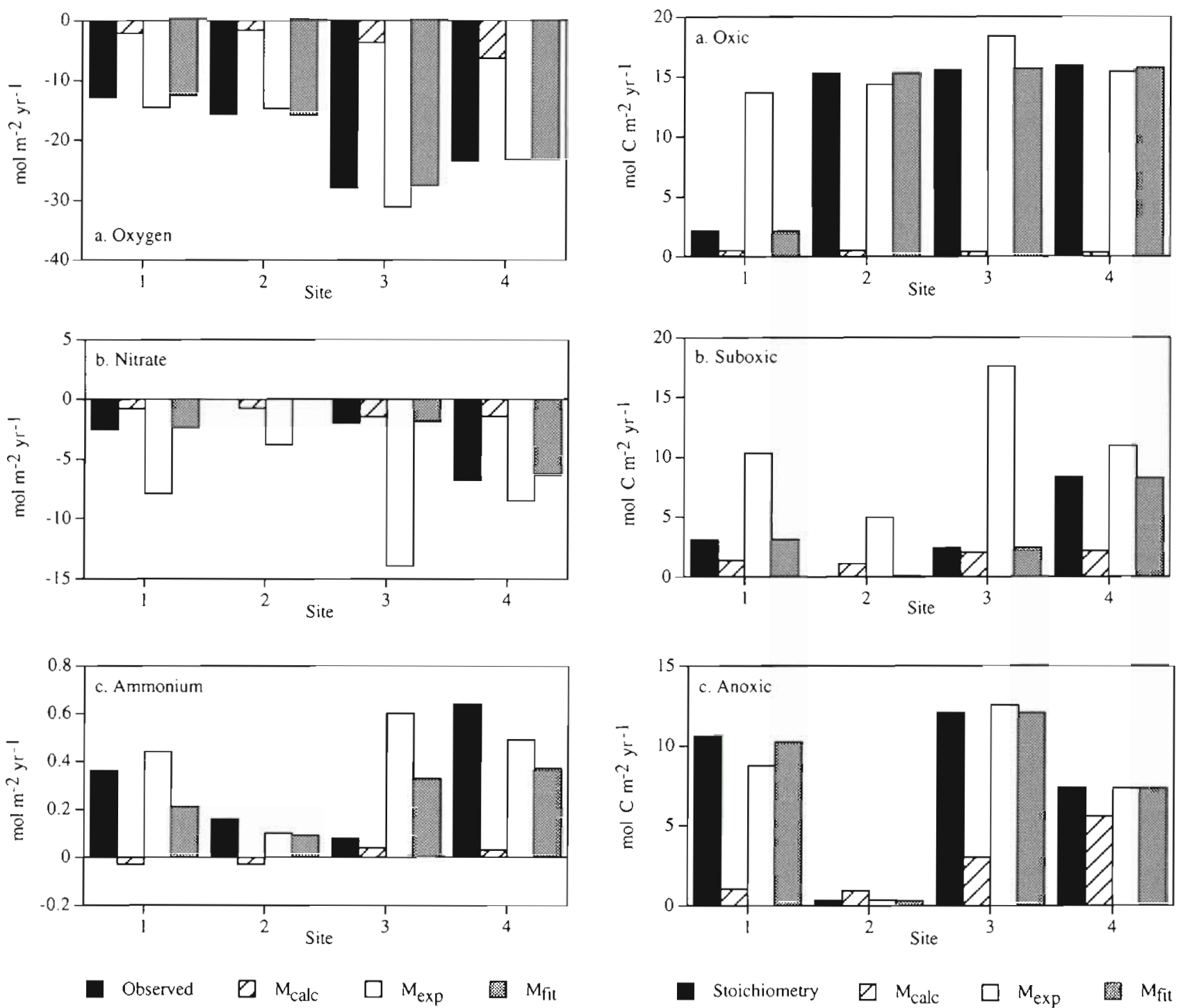

Fig. 3. Model and measured (Nedwell \& Trimmer 1996) solute exchange across the sediment water interface at 4 sites in the Gt Ouse estuary $\left(\mathrm{M}_{\mathrm{f} 1 \mathrm{t}}\right.$ : separate $k$ fitted to each mineralisation pathway; $\mathrm{M}_{\text {exp }}$ : $k$ defined by $k_{r}=k_{0} \mathrm{e}^{-\alpha z} ; \mathrm{M}_{\text {calr }}: k$ calculated from data, see text for further details. Note that observed data are annual integrals from 7 monthly measurements)

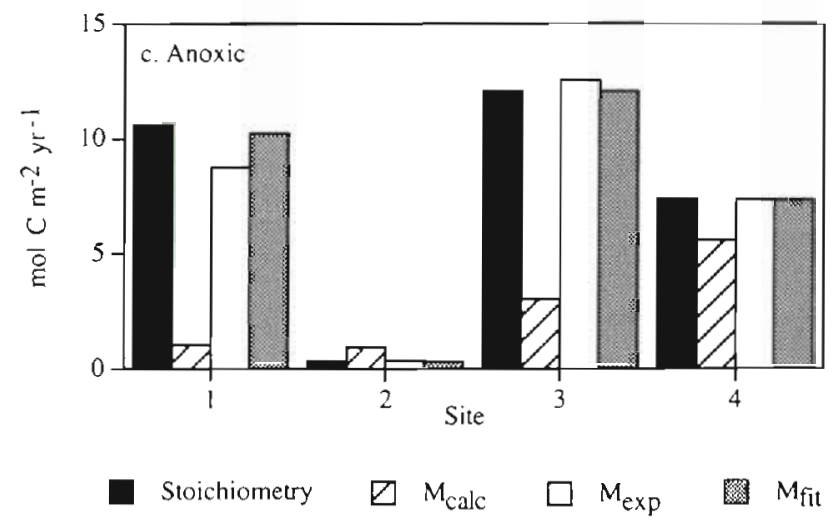

Fig. 4. Model and stoichiometric (Nedwell \& Trimmer 1996) calculations of oxic, suboxic and anoxic mineralisation rates and sulphate reduction rates at each site in the Gt Ouse estuary $\left(\mathrm{M}_{\mathrm{fil}}\right.$ : each mineralisation pathway fitted with separate $k_{i}$ $M_{\text {exp }}: k$ defined by an exponential function $k_{z}=k_{0} \mathrm{e}^{-a z}, M_{\text {calc }}$ : $k$ calculated from data, see text for details)

nitrate fluxes (Fig. 3b) across all sites do not correlate well $(r=0.06, p=0.75)$ with the measurements. Only at site 4 does the modelled nitrate flux of $8.49 \mathrm{~mol} \mathrm{NO}_{3}{ }^{-}$ $\mathrm{m}^{-2} \mathrm{yr}^{-1}$ compare favourably with the observed flux of $6.83 \mathrm{~mol} \mathrm{NO}_{3}^{-} \mathrm{m}^{-2} \mathrm{yr}^{-1}$. At Site 3, the model overestimates the nitrate flux by a factor of 7 and produces a flux of $3.80 \mathrm{~mol} \mathrm{NO}_{3}^{-} \mathrm{m}^{-2} \mathrm{yr}^{-1}$ at Site 2, where no significant fluxes were observed (Nedwell \& Trimmer 1996) Similarly, compared to measurements, ammonium fluxes in $\mathrm{M}_{\text {exp }}$ (Fig. 3c) are poorly modelled ( $\mathrm{r}=$ $0.04, p=0.81$ ). Removal of Site 3 results from the regression analysis, where the model overestimates

the measurement by a factor of 7.5, improves the fit $(\mathrm{r}=$ $0.77, \mathrm{p}=0.3)$. At Site 1 , the model flux $\left(0.44 \mathrm{~mol} \mathrm{NH}_{4}{ }^{+}\right.$ $\left.\mathrm{m}^{-2} \mathrm{yr}^{-1}\right)$ is higher than the observed flux $(0.36 \mathrm{~mol}$ $\mathrm{NH}_{4}^{+} \mathrm{m}^{-2} \mathrm{yr}^{-1}$ ), and at Sites 2 and 4 the model underestimates the observations.

$M_{\text {fit }}$ fluxes of oxygen and nitrate (Fig. 3a, b, respectively) compare well $(r=0.99, p<0.001)$ with observations at all sites. Note that nitrate release is modelled $\left(0.02 \mathrm{~mol} \mathrm{NO}_{3}{ }^{-} \mathrm{m}^{-2} \mathrm{yr}^{-1}\right.$ ) at Site 2 (Fig. 3b), where no significant nitrate fluxes were measured. Ammonium fluxes (Fig. 3c) in $M_{\text {fit }}$ are less well correlated $(r=0.67$, $p<0.33$ ) to the data. $M_{\text {fit }}$ fluxes are underestimated by 
approximately $40 \%$ (intersite mean) for Sites 1,2 and 4 and at Site 3 , the model ammonium flux $\left(0.29 \mathrm{~mol} \mathrm{NH}_{4}{ }^{+}\right.$ $\mathrm{m}^{-2} \mathrm{yr}^{-1}$ ) is 3.7 times greater than the observed flux (0.08 $\left.\mathrm{mol} \mathrm{NH}_{4}^{+} \mathrm{m}^{-2} \mathrm{yr}^{-1}\right)$.

\section{Mineralisation rates}

Fig. $4 \mathrm{a}-\mathrm{c}$ shows for each mineralisation pathway, the comparison of model $\left(M_{\text {calc }}, M_{\exp }\right.$ and $M_{\text {fit }}$ ) rates with the stoichiometric calculations of Nedwell \& Trimmer (1996). This stoichiometry is based on 4 independent pieces of information: (1) measured $\mathrm{C}: \mathrm{N}$ ratios (Table 1); (2) measured SWI fluxes; (3) measured sulphate reduction rates ( 2 and 3 are integrated to give annual values from the 7 monthly measurements); and 4) the stoichiometry of the mineralisation pathways of organic matter (see Eqs. 4 to 6 and Nedwell \& Trimmer 1996). Note that anoxic mineralisation (Eq. 6) is simply twice the measured rate of sulphate reduction. From hereon, the term stoichiometry will be used to describe the mineralisation rates derived by Nedwell \& Trimmer (1996).

$M_{\text {calc }}$ rates of mineralisation by all pathways (Fig. $4 \mathrm{a}-\mathrm{c}$ ) do not correspond well to the stoichiometric calculations. Rates of oxic mineralisation in $\mathrm{M}_{\text {calc }}$ (Fig. 4a) are $24 \%$ of the stoichiometrically determined rates for Site 1 , and less than $3 \%$ at the remaining sites. Nitrate based mineralisation (Fig. $4 \mathrm{~b}$ ) in $\mathrm{M}_{\text {calc }}$ yields carbon oxidation rates which are 44,83 and $26 \%$ of the stoichiometry at Sites 1,3 and 4, respectively. Anoxic mineralisation rates in $\mathrm{M}_{\text {calc }}$ (Fig. $4 \mathrm{c}$ ) are less than the stoichiometric rates at Sites 1,3 and 4 (1.06, 3.03, $5.57 \mathrm{~mol} \mathrm{C} \mathrm{m}^{-2} \mathrm{yr}^{-1}$ cf. $10.6,12.1,7.38 \mathrm{~mol} \mathrm{C} \mathrm{m}{ }^{-2} \mathrm{yr}^{-1}$, respectively) but greater at Site 2 by a factor of 2.9 .

$\mathrm{M}_{\text {exp }}$ rates of oxic mineralisation give a fit to the stoichiometry with a correlation of $r=0.33(p=0.43)$. At Sites 1 and 3, model oxic mineralisation (Fig. 4a) is, respectively, 6.3 and 1.2 times greater than that derived stoichiometrically. In contrast, at Sites 2 and 4. the model closely resembles stoichiometric oxic mineralisation. Suboxic mineralisation in $M_{\exp }$ (Fig. $4 \mathrm{~b}$ ) is higher than stoichiometric determinations at all sites. At Sites 1, 3 and 4, $M_{\text {exp }}$ overestimates the stoichiometric calculations by factors of $3.3,7.3$ and 1.3 , respectively. At Site 2, suboxic mineralisation is modelled at $4.94 \mathrm{~mol} \mathrm{C} \mathrm{m}^{-2} \mathrm{yr}^{-1}$ where a lack of significant measured fluxes of nitrate across the SWI led Nedwell \& Trimmer (1996) to conclude that suboxic mineralisation was absent. $M_{\text {exp }}$ rates of anoxic mineralisation (Fig. 4c) are similar to the stoichiometric rates (which are simply twice the measured rates of sulphate reduction) at all sites ( $r=0.96, p<0.02)$.

For all sites and pathways, $\mathrm{M}_{\mathrm{f} 1 \mathrm{t}}$ output compares well ( $r \geq 0.99, p \leq 0.001$ ) with the stoichiometry. Note that suboxic mineralisation (Fig. 4b) is modelled at Site 2 (0.09 $\left.\mathrm{mol} \mathrm{C} \mathrm{m} \mathrm{C}^{-2} \mathrm{yr}^{-1}\right)$ whereas the stoichiometric rate suggests a total absence of nitrate based carbon oxidation (see also the nitrate fluxes at Site 2, Fig. 3b).

\section{DISCUSSION}

The value of $k$ is a measure of the reactivity of TOC with depth (and time) and to a lesser extent the kinetic efficiency of the mineralisation pathways (Van Cappellen et al. 1993). The calculated $k$ values $\left(k_{\text {calc }}\right.$ Table 5) are at the lower limit of the range reported for a wide variety of coastal sediments (e.g. 0.1 to $4.8 \mathrm{yr}^{-1}$; McNichol et al. $1988 ; 0.005$ to $53 \mathrm{yr}^{-1}$, Andersen $1996 ; 0.2$ to $7 \mathrm{yr}^{-1}$; Middelburg et al. 1996) and suggests that the bulk organic matter at the Great Ouse sites is highly refractory with reactivity decreasing landward from Site 4 to Site 1 . Similarly, $k_{0}$, obtained with Eq. (12) (see Table 6), suggests that TOC reactivity decreases from Site 4 to Site 1 . This trend is reflected in the increase of the $C: N$ ratio towards the freshwater sites (Table 1). In comparison to $k_{\text {calc }}, k_{0}$ is $>2$ orders of magnitude higher at all sites. However, $k_{\text {calc }}$ and $k_{0}$ are not directly comparable. The latter reflects only the TOC reactivity at the SWI whereas $k_{\text {calc }}$, as previously mentioned, is the depth-integrated TOC reactivity of the sampled sediment column $(15 \mathrm{~cm})$. Thus $k_{\text {calc }}$ is uniform with depth while $k_{z}(z \geq 0)$ decreases exponentially away from the SWI. The degree to which $k_{z}(z \geq 0)$ decreases is determined by $\alpha$ (Eq. 12). At Sites 2, 3 and 4, $\alpha$ values (Table 6) are higher than those derived for other coastal areas (e.g. $\alpha<1$, Mackin \& Swider 1989), which suggests that the distribution of reactive organic matter is highly restricted to the upper sediment. Such distributions are typical of those observed in deep sea sediments (Emerson et al. 1985) where the amount of organic material reaching the sea floor is small enough to allow oxic mineralisation to dominate the consumption of reactive carbon (Bender \& Heggie 1984). In contrast, shallow areas usually experience high deposition of organic matter and a smaller proportion is degraded oxically within the usually very shallow surface oxic layer. Reactive carbon is buried below the oxic layer so pathways of anoxic degradation are more important in the sum of total benthic mineralisation (Jørgensen 1982). This case is suggested at Site 1 , where $k_{z}$ does not vary with depth $(\alpha=0$, Table 6$)$. In addition, Mackin \& Swider (1989) showed that in finegrained coastal sediments with lower overlying nitrate concentrations than that found in the Great Ouse, the lower the depth attenuation of reactive carbon (i.e. $\alpha$ ), the less oxygen contributes to total mineralisation. This may explain why at Site 1 Nedwell \& Trimmer 
(1996) calculated that oxygen contributed least (14\%) to total benthic mineralisation. This compares to between 50 and $98 \%$ at the other sites.

Values of $k$ derived for $\mathrm{M}_{\mathrm{fit}}$ (Table 6 ) reveal a similar trend between sites. $k_{02}$ decreases from Site 4 to Site 1 by more than an order of magnitude. This consistent pattern probably reflects the landward increase in the C: $N$ ratio (Table 1 ), which itself indicates an increase in both age and refractory nature of the bulk TOC. However, values of $k_{\text {so } 4}$ and $k_{\text {no3 }}$ do not show such a pattern. $k_{\text {no3 }}$ is least $\left(4.1 \times 10^{-4} \mathrm{yr}^{-1}\right)$ at Site 2 and highest (3.63 $\left.\mathrm{yr}^{-1}\right)$ at Site 4 while $k_{\mathrm{sO} 4}$ is maximum $\left(34.7 \mathrm{yr}^{-1}\right.$ ) at Site 1 and lowest $\left(0.25 \mathrm{yr}^{-1}\right)$ at Site 2 . In sediments where reactive organic carbon decreases with depth, it is expected that $k_{02}>k_{\text {no3 }}>k_{504}$. This pattern is only shown at Site 4 (Table 6). At Site $1 k_{\mathrm{so} 4}$ is $\sim 28$ times greater than $k_{02}$ and at Sites 2 and $3 k_{\text {so } 4}>k_{\text {no } 3}$. This can be indicative of at least 3 things: (1) that inputs of labile organic matter are high enough to allow most of the degradation to be anoxic; (2) that the sulphate reducing bacteria are more effective degraders than both aerobic and nitrate reducing bacteria for similar labile organic matter; or (3) that the type of material available for degradation is decomposed faster (and more easily) under anoxic conditions. (1) is usually explained by high accumulation rates of labile organic matter in excess of that which can be respired by oxygen (Jørgensen 1982). Rates of sedimentation $>0.1 \mathrm{~cm}$ $\mathrm{yr}^{-1}$ generally mean that sulphate is at least as important as oxygen in oxidising organic matter (Bralower \& Thierston 1987, Canfield 1989). High sedimentation rates would therefore explain why at Site 1 sulphate reduction accounts for nearly $70 \%$ of total carbon oxidation (Nedwell \& Trimmer 1996). In contrast, we have argued that in this narrow, fast flowing, canalised river, sedimentation is likely to be low and so a further explanation is required. The evidence concerning explanation (2) is conflicting. In some cases (e.g. Sun et al. 1993), anaerobic degradation rates have been shown to be faster than aerobic rates of decomposition, while in others (e.g. Benner et al. 1984) the opposite has been demonstrated. However, most of the evidence (e.g. Lee 1992, Harvey et al. 1995) suggests that there are no differences between aerobic and anaerobic decomposition rates. In support of the third explanation, Sun et al. (1993) have shown that degradation rate constants for diatom-derived chlorophyll a in intertidal sediments are up to 7 times greater under anoxic compared to oxic conditions. These authors point out that the differences in the rate constants are associated with the presence and quantity of particular types of structural associations of the degradable organic material (chlorophyll a). This means that organic material not easily degraded by aerobic bacteria can be more readily decomposed by anoxic microorganisms. We therefore propose that in these physically well-mixed sediments, the differences between $k_{\mathrm{o} 2}, k_{\text {no } 3}$ and $k_{\mathrm{so} 4}$ at Sites 1,2 and 3 reflect a higher lability of the organic carbon in the anoxic zone relative to the oxic layer. The nature of the organic material means that it is more reactive under anoxic conditions

\section{Model runs}

$M_{\text {calc }}$ runs yield poor comparisons with the data (Figs. $3 a-c \& 4 a-c$ ) because of the nature of the calculation of $k_{\text {calc }} \cdot k_{\text {calc }}$ represents a net value for carbon reactivity which accounts for all inhibiting and limiting factors that affect mineralisation rates. When $k_{\text {calc }}$ is implemented in the model, its value is reduced by the actions of $\operatorname{LimOx}_{1}$ and $\operatorname{InhibOx}_{2}$ (Eq. 2). The final value of $k_{\text {calc }}$, therefore, is the result of factors which are repeatedly accounted for, firstly (and implicitly), in the calculation and then in the model. This yields the low rate constants and thus the low model process rates.

The absolute magnitude of $k_{\text {calc }}$ depends strongly on the sediment depth considered, which itself is dependent on the depth over which mineralisation is assumed to be active. The smaller the depth considered, the higher the $k_{\text {calc }}$ value. For example, integration over the top $5 \mathrm{~cm}$ (instead of $15 \mathrm{~cm}$ ) of sediment would increase $k_{\text {calc }}$ by a factor of 3 . For the Great Ouse sites, this can only be considered at Site 1, where estimates of the depth of sulphate reduction are shown to be in the 0 to $5 \mathrm{~cm}$ depth range (Trimmer et al. 1997). At the only other site (Site 4) where similar estimates were made, active mineralisation occurred over the entire $15 \mathrm{~cm}$ sediment core (Trimmer et al. 1997). Recalculating $k_{\text {calc }}$ at Site 1 so that only the top $5 \mathrm{~cm}$ of sediment is integrated over, $k_{\text {calc }}$ is increased to $\sim 0.18 \mathrm{yr}^{-1}$. This is still much lower than the $k$ values derived for Site 1 in $M_{6 \mathrm{ft}}$ and $M_{\exp }$ (Table 6). Similar calculations for the other sites yield the same conclusions. Consequently, rate constants calculated via Method 1 and similar approaches (e.g. McNichol et al. 1988, Middelburg et al. 1996), while providing important information on the turnover times of bulk sedimentary organic carbon, should not be used in diagenetic models which include inhibition and limitation functions. Doing so will significantly reduce the value of the calculated rate constant.

The results of runs in $M_{\text {exp }}$ (Figs. $3 a-c \& 4 a-c$ ) show that the use of $k_{z}$ in the Great Ouse sediment sites does not reproduce the data consistently among the sites. Oxic mineralisation rates, total benthic oxygen demand and sulphate reduction rates are modelled satisfactorily. This suggests that $\alpha$ (in Eq. 12) yields a reasonable depth profile of reactive organic carbon (i.e. decreasing $k_{z}$, with depth). By implication, a factor 
other than $\alpha$ must be responsible for the high model nitrate fluxes (Fig. $3 b$ ) and denitrification rates (Fig. 4 b) at all sites. $k_{z}$ type formulations have been widely used (e.g. Mackin \& Swider 1989) and are comparable to diagenetic models which explicitly model organic carbon concentrations (e.g. Soetaert et al. 1996). However, these models have not been applied to regions where nitrate concentrations are as high as those in the Great Ouse (annual average $700 \mu \mathrm{M}$ ). At such high concentrations, nitrate no longer limits the rate of denitrification (Nedwell 1975, Nedwell \& Trimmer 1996, Trimmer et al. 1998). This has important consequences for the model. To illustrate this point, Fig. 5 compares the model profiles in the top $1 \mathrm{~cm}$ of sediment of $k_{\text {no3 }}$ (from $M_{\text {fit }}$ ) and $k_{2}$ (from $M_{\text {exp }}$ ) as applied in Eq. (8) (Table 2), for Site 3. The maximum possible values of these rate constants ( $\operatorname{Max} k_{\text {no3 }}$ and $\operatorname{Max} k_{z}$ ) are plotted alongside the actual model values. $k_{z}$ is a function of $\alpha$, the in situ nitrate concentration and oxygen inhibition. $k_{\text {no3 }}$ is only modified by nitrate and oxygen levels. Both rate constants increase in the first $1 \mathrm{~mm}$ as oxygen inhibition decreases (Fig. 5). At $2 \mathrm{~mm}$ depth, $k_{z}$ reaches a maximum of $7.4 \mathrm{yr}^{-1}$ compared to a maximum of $0.18 \mathrm{yr}^{-1}$ for $k_{\text {no3 }}$. The lower $k_{\text {no3 }}$ does not deplete the nitrate pool as fast as $k_{z}$. Consequently, nitrate remains less limiting (i.e. $\mathrm{NO}_{3}{ }^{-} \sim \mathrm{Ks}_{\mathrm{no}_{3}}$ Eq. 8 and Table 3 ) and $k_{\text {no3 }}$ is close to its maximum value $\left(\operatorname{Max} k_{\text {no3 }}\right.$ Fig $5 ; 0.19 \mathrm{yr}^{-1}$ Table 6). In contrast, $k_{z}$ between 1 and $3 \mathrm{~mm}$ depths, causes greater denitrification. At depths $>3 \mathrm{~mm}, k_{z}$ denitrification depletes nitrate to limiting concentrations and $k_{z}$ decreases faster with depth compared to $k_{\text {no3 }}$.

The higher $k_{z}$ near the SWI (depth $<4 \mathrm{~mm}$ ) is caused by 2 factors: (1) $k_{0}$ (Table 6), which is fitted to correspond well to measured oxygen fluxes (Fig. 3a), and (2) the nitrate removing capacity of denitrification. As oxygen concentrations become less inhibitory, the initial rate of denitrification increases. Opposing this increase is the corresponding decrease in nitrate concentrations. However, in this high nitrate environment, denitrification during this initial phase cannot remove enough nitrate for the nitrate to be sufficiently limiting (i.e. nitrate is not sufficiently less than $K s_{n o_{3}}$ Eq. 8). Consequently, $k_{z}$ cannot be reduced to a value (i.e. $k_{\text {no3 }}$ ) which gives the correct nitrate flux (see Fig. $3 \mathrm{~b}$, $\mathrm{M}_{\mathrm{fit}}$ vs measured value). Instead $k_{\mathrm{z}}$ at $2 \mathrm{~mm}$ is $\sim 41$ times greater than $k_{\text {no3 }}$, which therefore yields a high nitrate flux to the sediment.

It might be argued that the use of a $2-G$ model (Berner 1980a) may overcome these problems. The more labile fraction of TOC would be mostly mineralised by oxygen and the more refractory portion would be mostly mineralised by sulphate. The oxidation of sulphide (and ammonium) could account for the remainder of the observed oxygen demand. Thus, 1st order rate constant for organic decay $\left(\mathrm{yr}^{-1}\right)$

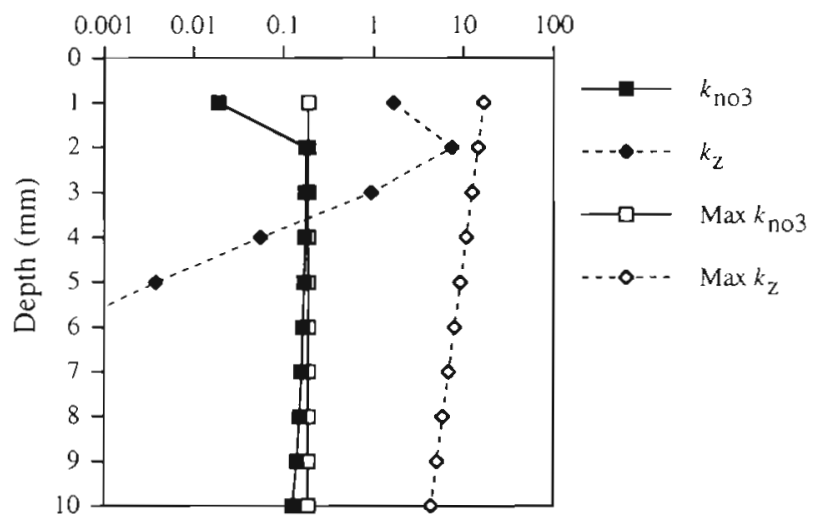

Fig. 5. Comparison of profiles for the top $1 \mathrm{~cm}$ of sediment of first order rate constants for denitrification, $k_{7}$ and $k_{\text {no3 }}$, at Site 3 . Both constants are modified by oxygen inhibition and nitrate limitation, see Eq. (8) in Table 2. For comparison, the maximum value of both rate constants is also profiled

denitrification would be the sum of the nitrate based carbon oxidation of part of the remainder of both fractions of TOC. We, therefore, split the measured TOC into 2 fractions: a labile part ( $=0.6 \%$ of the measured TOC (Nedwell 1987]) with an assumed Redfield C:N ratio of 6.6 , and a refractory part (the remainder) with the measured $\mathrm{C}: \mathrm{N}$ ratio (Table 1). Each fraction was modelled with its own $k_{0}$ and $\alpha$. This 2-G model could reproduce all observations, but with an unrealistic $k_{0}$ for the labile fraction of $>3 \times 10^{5} \mathrm{yr}^{-1}$ and a nitrification rate constant $>10^{6} \mathrm{yr}^{-1}$. The inverse linear dependency of the rate constant, $k_{0}$, to the TOC concentration means that an increase in the assumed percentage of the labile fraction of the TOC (i.e. $0.6 \%$ ) would decrease $k_{0}$. As this labile fraction is unknown and no alternative to the Nedwell (1987) quantification exists, tuning the fraction of TOC that is labile to the data would introduce greater uncertainty in the model.

We conclude that the use of exponential functions for describing organic mineralisation rates is not appropriate for sediments where overlying nitrate concentrations are high.

Some of the discrepancy between the $M_{\exp }$ model and the measured nitrate fluxes at Site 2 (Fig. 3b) may be due to the absence of advection in the model. Nedwell \& Trimmer (1996) note the occurrence of subsurface irrigation at this site which will influence porewater profiles. However, as the discrepancy between $M_{\exp }$ and observed nitrate fluxes occurs at all remaining sites, where it is reasonable to assume that diffusion is the dominant mode of solute transport (see assumptions), our conclusion remains.

Of the 3 model parameterisations tested, $M_{\mathrm{fit}}$ is the closest fit $(\mathrm{r}>0.99, \mathrm{p}<0.001)$ to both the observed 
solute fluxes across the SWI (Fig. $3 a-c$ ) and the stoichiometrically determined rates of mineralisation (Fig. $4 \mathrm{a}-\mathrm{c}$ ). The discrepancy between model results and those of Nedwell \& Trimmer (1996) for suboxic mineralisation and nitrate fluxes at Site 2 results from a modification in the way in which $k_{\text {no3 }}$ was derived. Setting $k_{\text {no3 }}=0$ to reproduce the observed zero flux of nitrate (Fig. 3b) would mean that denitrification was absent at this site. Although Nedwell \& Trimmer (1996) concluded that nitrate based carbon oxidation did not occur at Site 2, stoichiometric analysis showed that only $59 \%$ of the mineralised organic nitrogen left the sediment as ammonium. This indicates that coupled nitrification-denitrification occurred at this site (Nedwell \& Trimmer 1996) and thus carbon was oxidized by nitrate. Consequently, we derived $k_{\text {no3 }}$ by ensuring that $41 \%$ of the mineralised nitrogen was denitrified.

The goodness of fit of $M_{f i t}$ to the data is not surprising and only serves to validate the suitability of Berner's (1980a) general diagenetic equation for modelling sedimentary biogeochemical processes. Model fitting exercises are useful in extracting parameter values, but the $M_{\text {fit }}$ approach with its use of separate rate constants for each mineralisation pathway increases the degrees of freedom in the model and thus reduces conceptual simplicity. Given this, $M_{\text {fit }}$ ammonium effluxes compare less well to the data at all sites (Fig. 3c). At Site 3, the observed ammonium flux of $0.08 \mathrm{~mol} \mathrm{NH}_{4}{ }^{+}$ $\mathrm{m}^{-2} \mathrm{yr}^{-1}$ could be reproduced with a 10 -fold increase in the nitrification rate constant $\left(K_{\text {nit }}\right)$ to $127720 \mathrm{yr}^{-1}$ (350 $\mathrm{d}^{-1}$, cf. Table 3$)$. In contrast, at the remaining sites where model ammonium fluxes underestimate the observations, lower values for $K_{\text {nit }}$ could not replicate the data. A zero nitrification rate could only increase the ammonium efflux to $0.51 \mathrm{~mol} \mathrm{NH}_{4}{ }^{+} \mathrm{m}^{-2} \mathrm{yr}^{-1}$ (Site 4), to $0.14 \mathrm{~mol} \mathrm{NH}_{4}^{+} \mathrm{m}^{-2} \mathrm{yr}^{-1}$ (Site 2) and to $0.26 \mathrm{~mol}$ $\mathrm{NH}_{4}{ }^{+} \mathrm{m}^{-2} \mathrm{yr}^{-1}$ (Site 1) compared with observed fluxes of $0.64 \mathrm{moI} \mathrm{NH}_{4}^{+} \mathrm{m}^{-2} \mathrm{yr}^{-1}, 0.16 \mathrm{~mol} \mathrm{NH}{ }_{4}^{+} \mathrm{m}^{-2} \mathrm{yr}^{-1}$ and $0.36 \mathrm{~mol} \mathrm{NH}_{4}{ }^{+} \mathrm{m}^{-2} \mathrm{yr}^{-1}$, respectively. These differences may not be significant given the uncertainties associated with the calculation of the annually integrated SWI nutrient fluxes (i.e. the calculation is based on 7 monthly measurements). However, the deep oxygen penetration at Site 2 (Nedwell \& Trimmer 1996) suggests that a zero rate of nitrification is unlikely at this site. Alternatively, the deficit in the modelled ammonium flux at Sites 1, 2 and 4 may be due to either a lack of other mineralisation pathways in the model (e.g. iron and manganese reduction) or to a lack of model nitrate ammonification. Addition of alternative mineralisation pathways would contrast with the stoichiometric models of Nedwell \& Trimmer (1996) which showed that all of the measured ammonium fluxes could be accounted for by oxygen, nitrate and sulphate based carbon oxidation. In Nedwell \& Trimmer (1996), the measured benthic oxygen demand was accounted for by sulphide oxidation and 2 types of stoichiometry for oxic mineralisation: (1) where the nitrogen end product is ammonium (Eq. 4) and (2) where oxygen respiration is coupled to the production of $\mathrm{N}_{2}$ via nitrification-denitrification, i.e.

$\left(\mathrm{CH}_{2} \mathrm{O}\right)_{106}\left(\mathrm{NH}_{3}\right)_{16}+118 \mathrm{O}_{2}=106 \mathrm{CO}_{2}+8 \mathrm{~N}_{2}+130 \mathrm{H}_{2} \mathrm{O}$

Eq. (13) was used in cases where all of the measured ammonium flux could be accounted for by oxic mineralisation (Eq. 4) and sulphate reduction (Eq. 6) alone. To account for the remaining oxygen demand, oxygen respiration was coupled to nitrification-denitrification (Eq. 13). The absence of direct measurements of denitrification fuelled by nitrification (i.e. $D_{n}$ ) means that this cannot be verified. It is therefore possible that the oxygen could be used to reoxidise other reduced compounds such as iron $\left(\mathrm{Fe}^{2+}\right)$ or manganese $\left(\mathrm{Mn}^{2+}\right)$. In their oxidised form, iron and manganese could then be used to respire the same fraction of the organic carbon that would result via Eq. (13). This would not upset the mass balance for carbon in Nedwell \& Trimmer (1996). However, with this model the number of mineralisation pathways needed to satisfy the nitrogen budget would be increased. While it would be possible to incorporate additional pathways of organic decay and to calibrate the parameters (e.g. $k_{\mathrm{Fe}}$ for iron reduction) against the measured ammonium fluxes (and thereby improve the model fit), this would further increase the number of model parameters and thus the degrees of freedom. Additionally, the lack of data for iron and manganese in the Great Ouse sediments means that inclusion of processes related to these elements would amount to guesswork.

The alternative reason for the low model ammonium fluxes is a lack of nitrate ammonification. It has been suggested (Nedwell 1982, King \& Nedwell 1987, Trimmer et al. 1998) that in high nitrate environments like the Great Ouse, nitrate reduction will favour the denitrification pathway instead of nitrate ammonification. However, this does not rule out the presence of nitrate ammonification, which can account for $\leq 10 \%$ of the total nitrate reduction at nitrate concentrations in excess of $500 \mu \mathrm{M}$ (see Table 1 in Nedwell 1982). Similar percentages (4\% at Site 1 and $6 \%$ at Site 4 ) of the measured nitrate fluxes to the sediment (equivalent to total nitrate reduction) are required to account for the model deficit in ammonium fluxes (this calculation cannot be done at Site 2 due the zero nitrate flux measurement). We thus conclude that a lack of nitrate ammonification in the model is a likely cause for the underestimates in model ammonium fluxes. 


\section{CONCLUSIONS}

The first order rate constant $k$, represents the reactivity of sedimentary organic carbon and as such must decrease with depth and time (Berner 1980b). We have tested 3 ways of implementing $k$ in a diagenetic model for sediments subjected to high overlying nitrate concentrations: (1) The commonly used exponential formulation $\left(k_{z}=k_{0} \mathrm{e}^{-\alpha z}\right)$, while modelling oxic and anoxic processes well, overestimates measured nitrate fluxes because nitrate levels at these high concentrations cannot limit (reduce) the value of $k_{z}$ in the zone of denitrification. (2) Data calculated constants $\left(k_{\text {calc }}=\right.$ depth integrated total mineralisation rate $\div$ depth integrated carbon inventoryl underestimate diagenetic rates. Factors in the model (e.g. LimOx 1 ) that decrease the rate constant value with depth have already been accounted for in the calculation of $k_{\text {calc }}$. Consequently, the actual rate constant in the model is lowered. We conclude that $k$ values commonly derived in this way are not suitable in diagenetic models using limitation/ inhibition functions. (3) Fitting first order rate constants to individual pathways of mineralisation is the only way to satisfactorily reproduce the data. This increases the degrees of freedom in the model and, thus, casts doubt on the ability of diagenetic models for estuaries with high nitrate loads to be universally applicable.

Finally, the model $\left(\mathrm{M}_{\mathrm{ft}}\right)$ underestimates the observed ammonium fluxes at 3 sites. We propose that this is due to a neglect of other mineralisation pathways (e.g. nitrate ammonification) in the model which is likely to be active in the Great Ouse sediments.

Acknowledgements. This work was part of the JoNuSSONUS (Joint Nutrient Study Southern Nutrient Study) programme funded by the Ministry of Agriculture, Fisheries and Food, and the Department of the Environment, Transport and the Regions (all UK). The views expressed are those of the authors and do not reflect the policies of the funding departments. We thank Dr Dan Thornton for information concerning microphytobenthos and 3 anonymous reviewers for their comments which improved the quality of the manuscript.

Appendix 1. The finite difference form of the diffusion term in Eq. (1)

Direct differencing of the diffusion term yields

$$
\left.\frac{1}{\phi} \frac{\partial}{\partial z}\left(D_{c_{i}} \phi_{1} \frac{\partial \mathrm{C}}{\partial z}\right)_{j}\right)=-D_{c_{l}} \phi_{j} \frac{C_{1}-C_{j-1}}{\phi_{j} \mathrm{~d} z^{2}}+D_{c_{j+1}} \phi_{j+1} \frac{C_{i+1}-C_{i}}{\phi_{l} \mathrm{~d} z^{2}}
$$

Note that the $i$ and $j$ indices refer to the numerical grid scheme shown in Fig. 1. Thus the fully discretised form of the diagenetic reaction-diffusion Eq. (1) is

Rate of change $=-D_{c} \phi_{j} \frac{C_{i}-C_{i-1}}{\phi_{i} \mathrm{~d} z^{2}}+D_{c_{i+1}} \phi_{j+1} \frac{C_{i+1}-C_{i}}{\phi_{i} \mathrm{~d} z^{2}}+\sum R_{l}$ where $R_{1}$ for each grid cell is defined in Eqs. (7) to (11) (Table 2)

\section{LITERATURE CITED}

Andersen FO (1996) Fate of organic carbon added as diatom cells to oxic and anoxic marine sediment microcosms. Mar Ecol Prog Ser 134:225-233

Bender ML. Heggie DT (1984) Fate of organic carbon reaching the sea floor: a status report. Geochim Cosmochim Acta 48:977-986

Benner R, MacCubbin AE, Hodson RE (1984) Anaerobic degradation of the lignin and polysaccharide components of lignocellulose and synthetic lignin by sediment microflora. Appl Environ Microbiol 47:998-1004

Berner RA (1980a) Early diagenesis - a theoretical approach Princeton University Press, Princeton, NJ

Berner RA (1980b) A rate model for organic matter decomposition during bacterial sulfate reduction in marine sediments. In: Biogeochinie de la matiere organique a l'interface eau-sediment marine Colloq. Intl. CNRS 293:35-44

Billen G (1990) N-budget of the major rivers discharging into the continental coastal zone of the North Sea: the nitrogen paradox. In: Lancelot C, Billen G, Barth H (eds) Eutrophication and algal blooms in North Sea coastal zones, the Baltic and adjacent areas: prediction and assessment of preventive actions. Commission of the European Communities, Brussels, p 153-171

Blackburn TH, Blackburn ND (1993) Rates of microbial processes in sediments. Phil Trans R Soc Lond A 344:49-58

Boudreau BP (1995) A method of lines code for carbon and nutrient diagenesis in aquatic sediments. Computers Geosciences $22: 479-496$

Bralower TJ, Thierston HR (1987) Organic carbon and metal accumulation rates in Holocene and mid-Cretaceous sediments: palaeoceanographic significance. In: Brooks J, Fleet AJ (eds) Marine petroleum source rocks. Blackwell Scientific Publications, Oxford, p 345-369

Canfield D (1989) Sulfate reduction and oxygen respiration in marine sediments: implications for organic carbon preservation in euxinic environments. Deep-Sea Res 36:121-138

Dhakar SP, Burdige DJ (1996) A coupled non-linear steady state model for early diagenetic processs in pelagic sediments. Am J Sci 296:296-330

Emerson S, Fischer K, Reimers C, Heggies D (1985) Organic carbon dynamics and preservation in deep sea sediments. Deep-Sea Res 32:1-21

Gould DJ, Dyer MF, Tester DJ (1987) Environmental quality and ecology of the Great Ouse estuary. Wat Pollut Control $86: 84-103$

Harvey HR, Tuttle JH, Bell JT (1995) Kinetics of phytoplankton decay during simulated sedimentation: changes in biochemical composition and microbial activity under oxic and anoxic conditions. Geochim Cosmochim Acta 59(16): $3367-3377$

Howarth RW, Billen D, Swaney D, Townsend A, Jaworski N, Lajtha K, Downing JA, Elmgreen R, Caraco $N$, Jordan $T$, Berendse $F$. Freney J, Kudeyarov V, Murdoch P, ZhaoLiang $Z$ (1996) Regional nitrogen budgets and riverine $N$ \& P fluxes for the drainages to the North Atlantic Ocean: natural and human influences. Biogeochemistry 35: $75-139$

Iversen N, Jørgensen BB (1993) Diffusion coefficients of sulfate and methane in marine sediments: influence of porosity. Geochim Cosmochim Acta 57:571-578

Jorgensen BB (1982) Mineralisation of organic matter in the sea bed-the role of sulfate reduction. Nature 296: $643-645$

King D, Nedwell DB (1987) The adaptation of nitratereducing bacterial communities in estuarine sediments in 
response to overlying nitrate load. FEMS Microbiol Ecol $45: 15-20$

Lee C (1992) Controls on organic carbon preservation: the use of stratified water bodies to compare intrinsic rates of decomposition in oxic and anoxic systems. Geochim Cosmochim Acta 56:3323-3335

Li YH, Gregory S (1974) Diffusion of ions in sea water and in deep sea sediments. Geochim Cosmochim Acta 38:703-714

Mackin JE, Swider KT (1989) Organic matter decomposition pathways and oxygen consumption in coastal marine sediments. J Mar Res 47:681-716

McNichol AP, Lee C, Druffel, ERM (1988) Carbon cycling in coastal sediments: 1 . A quantitative estimate of the remineralisation of organic carbon in the sediments of Buzzards Bay, Mass. Geochim Cosmochim Acta 52:1531-1543

Middelburg JJ, Klaver G, Nieuwenhuize J, Wielemaker A, de Haas W, Vlug $T$, van der Nat JFWA (1996) Organic mineralisation in intertidal sediments along an estuarine gradient. Mar Ecol Prog Ser 132:157-168

Middelburg JJ, Soetaert K, Herman PMJ, Heip CHR (1996) Denitrification in marine sediments: a model study. Global Biogeochem Cycles 10:661-673

Nedwell DB (1975) Inorganic nitrogen metabolism in a eutrophicated tropical mangrove estuary. Water Res 9:221

Nedwell DB (1982) Exchange of nitrate and the products of bacterial nitrate reduction between seawater and sediment from a UK saltmarsh. Estuar Coast Shelf Sci 14: $557-566$

Nedwell DB (1987) Distribution and pool sizes of microbially available carbon in sediment measured by a microbiological assay. FEMS Microbiol Ecol 45:47-52

Nedwell DB, Trimmer M (1996) Nitrogen fluxes through the upper estuary of the Great Ouse, England: the role of the bottom sediments. Mar Ecol Prog Ser 142:273-286

Editorial responsibility: Otto Kinne (Editor)

Oldendorf/Luhe, Germany
Rabouille C, Gaillard JF (1991) A coupled model representing the deep sea organic carbon mineralisation and oxygen consumption in surficial sediments. J Geophys Res 96: $2761-2776$

Soetaert K, Herman PMJ, Middelburg JJ (1996) A model of early diagenetic processes from the shelf to abyssal depths. Geochum Cosmochim Acta 60:1019-1040

Sun MY, Lee C, Aller RC (1993) Laboratory studies of oxic and anoxic degradation of chlorophyll-a in Long Island Sound sediments. Geochim Cosmochim Acta 57:147-157

Trimmer M, Purdy KJ, Nedwell DB (1997) Process measurement and phylogenetic analysis of the sulfate reducing bacterial communities of two contrasting benthic sites in the upper estuary of the Great Ouse, Norfolk, UK. FEMS Microbiol Ecol 24:333-342

Trimmer M, Nedwell DB, Sivyer DB, Malcolm SJ (1998) Nitrogen fluxes through the lower estuary of the river Great Ouse, England: the role of the bottom sediments. Mar Ecol Prog Ser 163:109-124

Tromp TK, Van Cappellan P, Key RM (1995) A global model for the early diagenesis of organic carbon and organic phosphorus in marine sediments. Geochim Cosmochim Acta 59:1259-1284

Ullman WJ, Aller RC (1982) Diffusion coefficients in nearshore marine sediments. Limnol Oceanogr 27:552-556

Van Cappellen P, Gaillard JF, Rabouille C (1993) Biogeochemical transformations in sediments: kinetic models of eary diagenesis. In: Wollast $R$, Mackenzie FT, Chou $L$ (eds) Interactions of $\mathrm{C}, \mathrm{N}, \mathrm{P}$ and $\mathrm{S}$ biogeochemical cycles and global change. Springer-Verlag, Berlin, p 401-446

Wang $Y$, Van Cappellen P (1996) A multicomponent reactive transport model of early diagenesis: application to redox cycling in coastal marine sediments. Geochim Cosmochim Acta 60:2993-3014

Submitted: September 5, 1997; Accepted: September 9, 1998 Proofs received from author(s): January 22, 1999 